\title{
HUBUNGAN KARAKTERISTIK INDIVIDU TERHADAP PENILAIAN KUALITAS PRODUK APOTEK RAWAT JALAN
}

\author{
THE RELATIONSHIP OF INDIVIDUAL CHARACTERISTIC TOWARDS \\ PRODUCT QUALITY ASSESMENT OF OUTPATIENT PHARMACY
}

Ade Nurma Ruditya, Djazuly Chalidyanto

Fakultas Kesehatan Masyarakat, Universitas Airlangga, Surabaya E-mail: adenurmaruditya@gmail.com

\begin{abstract}
Pharmacy services in hospitals need special attention to achieve effectiveness and efficiency of quality dimensions. Achievement of customer satisfaction figures in Dr. Moewardi Pharmacy Hospital Surakarta didn't meet hospital standards that set in the amount of $\geq 80 \%$ over the years 2013 to 2014, especially in the outpatient pharmacy. The purpose of this research is to study the relationship between the individual factors of patient (age, sex, educational level, employment status, income level) to product quality assessment in an outpatient pharmacy. This research is an observational analytic with cross sectional study design. Data was collected by interview using a questionnaire. Analyzed using univariate and bivariate analysis. The Results of the analysis of the factor that were significantly associated with the assessment of product quality are age and employment status. The majority of respondents give high scores for product quality assessment. Individual patient factors associated with product quality assessment in outpatient pharmacies are age and employment status. Need to maintain the quality of existing products, and specifically to the dimensions of the product's features need to increase in order to better product quality.
\end{abstract}

Keywords: pharmacy services, individual factors, products quality

\section{PENDAHULUAN}

Keputusan Menteri Kesehatan Republik Indonesia No. 129/Menkes/SK/II/2008 tentang Standar Minimal Pelayanan Rumah Sakit menyebutkan bahwa, rumah sakit sebagai salah satu fasilitas pelayanan kesehatan perorangan merupakan bagian dari sumber daya kesehatan yang sangat diperlukan dalam mendukung penyelenggaraan upaya kesehatan. Berdasarkan Keputusan Menteri Kesehatan Republik Indonesia No. 1197/MENKES/SK/X/2004 tentang Standar Pelayanan Farmasi di Rumah Sakit menyebutkan bahwa, pelayanan farmasi rumah sakit merupakan salah satu kegiatan yang menunjang pelayanan kesehatan yang bermutu di rumah sakit. Instalasi Farmasi Rumah Sakit merupakan unit yang mengemban tugas dan tanggungjawab pada pengelolaan seluruh aspek yang berkaitan dengan obat atau perbekalan kesehatan yang beredar dan digunakan di rumah sakit tersebut. Pelayanan Farmasi perlu menjadi perhatian penting dalam upaya tercapainya dimensi mutu seperti efektivitas dan efisiensi pelayan. Tercapainya mutu pelayanan yang baik perlu menggunakan suatu standar yang telah ditetapkan dengan indikator yang merupakan suatu alat atau tolok ukur, salah satunya adalah Standar Pelayanan Minimal (SPM). Rumah sakit menetapkan standar sendiri dalam SPM rumah sakit untuk dipatuhi agar tercapai tujuan dari rumah sakit tersebut.

Berdasarkan laporan SPM RSUD Dr. Moewardi Surakarta, waktu tunggu pelayanan Instalasi Farmasi pada RSUD Dr. Moewardi Surakarta lebih cepat dari tahun 2013 ke tahun 2014. Hal tersebut menunjukan salah satu perbaikan pelayanan yang diberikan oleh Intalasi Farmasi. Perbaikan pelayanan kefarmasian yang ditunjukan oleh indikator waktu tunggu diharapkan meningkatkan 
kepuasan pelanggan Instalasi Farmasi. Waktu tunggu dapat mempengaruhi kepuasan pelanggan yang memanfaatkan pelayanan kefarmasian. Berdasarkan laporan SPM RSUD Dr. Moewardi Surakarta, meskipun waktu tunggu sudah cepat tetapi kepuasan pelanggan belum mencapai target yang telah ditetapkan. Rumah sakit telah melakukan survey kepuasan pelanggan setiap bulan untuk semua aspek baik kualitas layanan maupun kualitas produk, meskipun untuk kualitas produk masih belum mencangkup semua dimensi. Masalah yang diangkat dalam penelitian ini adalah tidak tercapainya angka kepuasan pelanggan Instalasi Farmasi RSUD Dr. Moewardi Surakarta sesuai standar yang ditetapkan rumah sakit yaitu sebesar $\geq$ 80\% selama tahun 2013-2014 terutama di Apotek Rawat Jalan RSUD Dr. Moewardi Surakarta.

Penelitian ini bertujuan untuk mempelajari hubungan faktor individu pasien (umur, jenis kelamin, tingkat pendidikan, status pekerjaan, tingkat pendapatan) terhadap penilaian kualitas produk di Apotek Rawat Jalan RSUD Dr. Moewardi Surakarta. Faktor individu mempengaruhi setiap penilaian dan keinginan pasien terhadap produk yang diberikan oleh rumah sakit. Penelitian yang dilakukan diharapkan dapat menjadi sumber informasi mengenai penilaian tentang dimensi kualitas produk menurut pasien atau pelanggan di Instalasi Farmasi RSUD Dr. Moewardi Surakarta. Adanya informasi ini diharapkan dapat digunakan sebagai masukan rumah sakit dalam perencanaan dalam rancangan produk dan evaluasi.

\section{PUSTAKA}

\section{Kepuasan Pelanggan}

Anderson, dkk., (1994) menerangkan bahwa pengalaman pelanggan dalam membeli dan menggunakan secara keseluruhan suatu produk baik barang maupun jasa merupakan kepuasan pelanggan. Pelanggan yang merasa puas akan layanan dan produk yang diberikan menciptkakan kemungkinan yang besar untuk menjadi pelanggan dalam waktu panjang. Kepuasan pelanggan menjadi faktor penting dalam kehidupan suatu perusahaan, selain itu memuaskan pelanggan dapat meningkatkan keunggulan dalam persaingan. Zeithaml dan Bitner (2003), mengemukakan bahwa kepuasan adalah konsep yang lebih luas dari sekedar penilaian kualitas pelayanan, tetapi juga di pengaruhi oleh faktor lain. Kotler (1997) menyatakan bahwa kepuasan pelanggan dapat diukur dengan beberapa metode, yaitu: sistem saran serta keluhan pelanggan, pengecekan kepuasan pelanggan melalui survei, pelanggan bayangan, menganalisis pelanggan yang hilang atau tidak menggunakan produk lagi. Persepsi pasien terhadap kualitas layanan, harga, kualitas produk, faktor situasi dan karakter individu mempengaruhi kepuasan pelanggan (Zeithaml dan Bitner, 1996).

\section{Kualitas Produk}

Kepuasan pelanggan dan keberhasilan perusahaan untuk bersaing didasarkan oleh kualitas (Mulyono, dkk., 2007). Menurut Widyaswati (2010) definisi kualitas adalah keseluruhan karakteristik dan 
ciri dari sebuah produk atau jasa yang menunjukkan kemampuannya untuk memuaskan kebutuhan yang tersirat. Berdasarkan beberapa definisi tersebut dapat disimpulkan bahwa kualitas suatu produk dapat dirasakan apabila produk yang dijual telah sesuai dengan harapan pelanggan.

Menurut Brucks, Zeithaml, dan Naylor (2000) dalam melakukan studi tentang persepsi konsumen terhadap kualitas barang tahan lama menyatakan bahwa kualitas produk yang dirasakan memainkan peran penting yang mempengaruhi pilihan pembelian. Kualitas berkaitan dengan pemenuhan permintaan, atau melebihi permintaan konsumen, sehingga produk harus memenuhi kebutuhan dan cocok dengan penggunaan konsumen (Arifianti, 2013). Manfaat bagi pelanggan yang dihasilkan dari cerminan keseluruhan dimensi penawaran produk merupakan kualitas (Tjiptono, 2008).

Terdapat delapan dimensi kualitas produk, yaitu: performance product, features product, reliability product, conformance product, durability product, service ability, aesthetics product, perceive quality product (Tjiptono, 2008). Kinerja ini merupakan faktor dasar operasi suatu produk. Fitur dapat berbentuk atribut tambahan yang melengkapi atau meningkatkan fungsi produk inti dan karena berperan sebagai pelengkap, maka sifatnya fleksibel terhadap perubahan. Reliability merupakan kemampuan produk untuk bertahan dari kemungkinan mengalami keadaan malfunction pada suatu periode tertentu. Kesesuaian di sini berkaitan dengan tingkat kesesuaian produk terhadap spesifikasi yang ditetapkan sebelumnya berdasarkan keinginan pelanggan atau tidak ditemukannya cacat pada produk. Durability yaitu usia produk tersebut dari awal hingga produk perlu diganti yang baru. Service ability meliputi ketangkasan, kompetensi, keramahan, serta kemudahan pasien dalam mendapatkan layanan dari pekerja. Aesthetics berhubungan dengan bagaimana penampilan produk. Perceived quality mencakup kategori reputasi merek termasuk pengaruh citra merek dan faktor tidak berwujud lainnya yang dapat mempengaruhi persepsi konsumen terhadap kualitas. Citra merek adalah merek suatu produk telah dianggap sebagai kelompok asosiasi sehingga sebagai penghubung penilaian konsumen terhadap suatu merek (Biel, 1992). Citra merek merupakan kepercayaan pelanggan terhadap suatu merek produk tertentu (Dobni and Zinkhan, 1990).

\section{Perilaku Pelanggan}

Kegiatan pelanggan dalam mencari, membeli, mengonsumsi, menilai, dan mengganti suatu produk merupakan perilaku pelanggan (Schiffman dan Kanuk, 2000). Perilaku konsumen tersebut adalah gambaran bagaimana konsumen memilih, menggunakan dan mengevaluasi barang maupun jasa yang digunakan. Menurut Swastha dan Handoko (2000), perilaku pelanggan yaitu kegiatan seseorang yang secara langsung memanfaatkan suatu produk. Persepsi konsumen terhadap kuallitas produk berbeda antara konsumen satu dengan yang lain (Yulie, 2008). Menurut Pasuraman (1990), penilaian pelanggan terhadap kualitas suatu layanan maupun produk tergantung oleh dua hal yaitu 
harapan dan persepsi pelanggan. Pelanggan memiliki karakteristik evaluasi yang berbeda pada produk yang digunakan.

Perilaku pelanggan atau pasien terhadap suatu produk dipengaruhi oleh beberapa faktor, dijelaskan dalam teori perilaku konsumen oleh Kotler (2004), yaitu: budaya, sosial, karakteristik individu, dan psikologi. Faktor budaya, Kotler (2001) menyatakan bahwa keinginan serta perilaku pelanggan dalam mendapatkan evaluasi, prefrensi, persepsi, dan perilaku lembaga lain ditentun oleh budaya. Faktor sosial, seperti kelompok acuan, keluarga, refrensi, status serta peran sosial mempengaruhi perilaku pelanggan (Kotler dan Keller, 2009). Faktor individu, karakteristik individu seseorang yang berbeda dengan orang lain yang menyebabkan penilaian yang relatif konsisten dan bertahan lama terhadap lingkungan terdiri dari umur, jenis kelamin, tingkat pendidikan, status pekerjaan, tingkat pendapatan. Faktor psikologis, menurut Lamb dkk. (2001), bagaimana seseorang mengetahui mengumpulkan, menganalisis, merumuskan ide dan pendapat yang dilanjutkan sebagai cara untuk memutuskan suatu tindakan. Berdasarkan teori di atas, dapat diketahui bahwa perilakui konsumen salah satunya dipengaruhi oleh faktor individu atau karakteristik individu. Banyaknya karakteristik individu ini memberikan dampak langsung pada perilaku pelanggan, penting bagi perusahan menggetahui sebagai salah satu pendekatan untuk pemasaran.

\section{METODE}

Pengambilan data di lapangan untuk penelitian ini dilakukan pada bulan April-Juli 2015. Penelitian ini merupakan observasional analitik dengan rancang bangun cross sectional. Lokasi untuk penelitian ini adalah di bagian Apotek Rawat Jalan RSUD Dr. Moewardi Surakarta. Populasi penelitian ini adalah semua pasien yang menggunakan layanan Apotek Rawat Jalan RSUD Dr. Moewardi Surakarta, yang dihitung dari rerata lembar resep di apotik rawat jalan per bulan periode JanuariDesember 2014. Besar sampel pada penelitian ini sebesar 96 pasien. Pengambilan sampel diperlukan 7 pasien setiap hari. Interval pengambilan sampel dilakukan dengan teknik systematic random sampling.

Kriteria sampel penelitian adalah pasien yang menggunakan pelayanan di Apotek Rawat Jalan RSUD Dr. Moewardi Surakarta, sadar dan mampu berkomunikasi, berumur 15-65 tahun, pernah menggunakan produk di Apotek Rawat Jalan RSUD Dr. Moewardi Surakarta, bersedia menjadi responden penelitian, bersedia mengisi kuesioner dan diwawancarai. Pengumpulan data dilakukan dengan wawancara dengan menggunakan kuesioner yang dilakukan pada satu kali waktu. Analisis hubungan korelasi menggunakan uji korelasi Spearman dan uji Chi-Square.

\section{HASIL DAN PEMBAHASAN}

\section{Karakteristik Individu Pasien}

Karakteristik individu adalah faktor dalam diri seseorang yang menggerakan serta mempangaruhi tindakan seseorang (Hurriyati, 2005). Kebutuhan individu dalam memanfaatkan pelayanan kesehatan dipengaruhi secara langsung oleh karakteristik individu, sedangkan faktor tidak langsung 
Tabel 1 Distribusi Karakteristik Individu Pasien Apotek Rawat Jalan RSUD Dr. Moewardi Surakarta.

\begin{tabular}{|c|c|c|}
\hline Karakteristik Individu Pasien & Jumlah (Orang) & Persentase (\%) \\
\hline \multicolumn{3}{|l|}{ Umur } \\
\hline Remaja & 17 & 17,7 \\
\hline Dewasa & 43 & 44,8 \\
\hline Lansia & 36 & 37,5 \\
\hline \multicolumn{3}{|l|}{ Jenis Kelamin } \\
\hline Laki-laki & 34 & 35,4 \\
\hline Perempuan & 62 & 64,6 \\
\hline \multicolumn{3}{|l|}{ Tingkat Pendidikan } \\
\hline$\leq$ Tamat SMP & 35 & 36,5 \\
\hline Tamat SMA & 37 & 38,5 \\
\hline Tamat PT/Akademi & 24 & 25,0 \\
\hline \multicolumn{3}{|l|}{ Status Pekerjaan } \\
\hline Tidak Bekerja & 60 & 62,5 \\
\hline Bekerja & 36 & 37,5 \\
\hline \multicolumn{3}{|l|}{ Tingkat Pendapatan } \\
\hline$<$ UMR & 53 & 55,2 \\
\hline$\geq$ UMR & 43 & 44,8 \\
\hline
\end{tabular}

dipengaruhi oleh sosio ekonomi dan budaya (Hutapea, 2009). Distribusi faktor individu pasien Apotek Rawat Jalan RSUD Dr. Moewardi Surakarta ditunjukan pada Tabel 1.

Pasien yang datang di Apotek Rawat Jalan RSUD Dr. Moewardi Surakarta mayoritas pada kelompok umur dewasa (26-45 tahun), berjenis kelamin perempuan, mempunyai latar belakang pendidikan tamat SMA, tidak bekerja, dan memiliki pendapatan kurang dari UMR. Mayoritas pasien yang berasal dari kelompok umur dewasa dikarenakan pada usia tersebut pasien lebih mudah untuk mengakses pelayanan kesehatan dibanding dua kelompok umur lain secara mandiri. Menurut Olson dan Peter (2000), kelompok umur yang berbeda memberikan perilaku yang berbeda. Umur dewasa memiliki cara berfikir dan mengambil keputusan yang optimal dan mandiri. Umur sangat berpengaruh terhadap karakteristik biografis individu.

Banyaknya pasien dengan usia dewasa juga disebabkan banyaknya pasien wanita. Penggunaan pelayanan kesehatan oleh wanita lebih tinggi dibandingkan dengan laki-laki. Hal tersebut dikarenakan wanita mempunyai kejadian dan risiko penyakit yang lebih besar dibandingkan dengan lakilaki. Indikator fisiologis yang berbeda (umur dan jenis kelamin) dan siklus hidup menunjukan asumsi bahwa perbedaan derajat kesehatan, derajat kesakitan dan penggunaan pelayanan kesehatan sedikit banyak akan berhubungan dengan data demografi tersebut (Notoatmodjo, 2010).

Tingkat pendidikan seseorang sangat berhubungan dengan kualitas kesehatan seseorang agar lebih baik. Tingkat pendidikan seseorang yang lebih tinggi akan cenderung memiliki perilaku hidup yang lebih sehat dibandingkan dengan yang tidak. Menurut Notoatmodjo (2003) pengetahuan merupakan stimulus bagi health seeking behavior, yaitu perilaku seseorang dalam mencari pengobatan. Penelitian ini menunjukkan bahwa mayoritas responden yang tidak bekerja adalah berjenis kelamin perempuan. Mayoritas responden yang berjenis kelamin perempuan ini kebanyakan hanya sebagai ibu rumah tangga. Angka kerja wanita lebih kecil dibandingkan dengan laki-laki sehingga kesediaan meluangkan waktu untuk pelayanan kesehatan juga jauh lebih besar 
Tabel 2 Distribusi Penilaian Dimensi Kualitas Produk di Apotek Rawat Jalan RSUD Dr. Moewardi Surakarta.

\section{Kinerja Produk}

Tinggi

Rendah

Fitur Produk

Tinggi

Rendah

Daya Tahan Produk

Tinggi

Rendah

Service Ability

Tinggi

Rendah

Kehandalan Produk

Tinggi

Rendah

Kesesuaian Produk

Tinggi

Rendah

Aesthetic Produk

Tinggi

Rendah

Perceived Quality Produk

Tinggi

Rendah

dibandingkan dengan laki-laki. Menurut Kotler dan

Keller (2009), pekerjaan dan keadaan ekonomi

suatu keluarga adalah pengaruh besar terhadap

perilaku konsumen. Pendapatan adalah segala

sesuatu yang diterima baik uang maupun barang

baik dari pihak lain maupun dari hasil diri sendiri

yang dinilai sesuai dengan harga yang berlaku saat

ini (Wijaksana, 1992). Tingkat pendapatan

menggambarkan tingkat dan kondisi ekonomi suatu

keluarga. Hal tersebut dikarenakan banyaknya

responden yang tidak bekerja, sehingga pendapatan

keluarganya sedikit atau di bawah UMR.

\section{Penilaian Kualitas Produk}

Gambaran penilaian dimensi kualitas produk di Apotek Rawat Jalan RSUD Dr. Moewardi Surakarta oleh pasien ditunjukan pada Tabel 2. Jumlah (Orang) Persentase (\%)

83,3

16,7

16

34,4

33

65,6

63

81

84,4

15

16,6

65

67,7

31

32,3

57

59,4

39

40,6

82

85,4

14

14,6

62

34

64,6

35,4

$\begin{array}{ll}53 & 55,2 \\ 43 & 44,8\end{array}$

Penilaian kualitas produk secara keseluruhan mendapatkan penilaian yang tinggi dari pasien. Penilaian kualitas produk oleh pasien dilakukan dengan mengisi kuesioner yang telah diberikan oleh peneliti. Kuesioner berisi mengenai penilaian pasien berdasar setiap dimensi produk. Tjiptono (2008) menjelaskan, paduan antara karakteristik dan sifat penentu sejauh mana produk memenuhi syarat kebutuhan dan menilai sejauh mana kebutuhan pelanggan terpenuhi yaitu disebut kualitas produk. Penilaian kualitas produk yang dinilai mencakup kinerja produk, fitur produk, daya tahan produk, service ability, kehandalan produk, kesesuaian produk, aesthetic produk, dan perceived quality produk. Meskipun secara keseluruhan penilaian kualitas produk sudah tinggi, tetapi mayoritas responden menilai fitur produk masih rendah. 
Penilaian yang rendah dari pasien untuk fitur produk dikarenakan kurangnya variasi kemasan produk yang telah diberikan.

Secara keseluruhan penilaian untuk kualitas produk yang diberikan oleh mayoritas pasien adalah tinggi. Setelah dilakukan perhitungan, jumlah pasien yang memberikan penilaian tinggi untuk kualitas produk sebesar 66, 7\%. Untuk pasien yang memberikan penilaian yang rendah untuk kualitas produk sejumlah 33, 3\%. Persepsi konsumen terhadap kualitas produk berbeda antara konsumen satu dengan yang lain (Yulie, 2008).

\section{Hubungan Karakteristik Individu Pasien terhadap Penilaian Kualitas Produk Apotek Rawat Jalan RSUD Dr. Moewardi Surakarta}

Kanuk dan Schiffman (2004) menyatakan bahwa kegiatan yang ditunjukan oleh pelanggan untuk membeli, menggunakan, menilai, dan mengganti produk atau jasa yang digunakan agar mencapai kepuasan adalah perilaku pelanggan. Faktor individu atau karakteristik individu adalah suatu dalam diri seseorang yang menghasilkan bagaimana individu tersebut mendapatkan, menerima, dan menggunakan suatu produk serta pengalamannya (Hurriyati, 2005).

Analisis menunjukan karakteristik individu yang terbukti berhubungan dengan penilaian kualitas produk adalah umur dan status pekerjaan. Umur berhubungan dengan kualitas produk karena pada setiap kelompok umur memiliki cara berfikir yang mulai berbeda. Semakin bertambahnya umur atau semakin tua maka penilaian yang diberikan terhadap kualitas produk semakin tinggi. Hal tersebut dikarenakan pada usia yang semakin tua memiliki penerimaan yang lebih baik sehingga tuntutan dari suatu produk akan berkurang. Menurut Peter dan Olson (2000), kelompok umur yang berbeda lebih banyak memberikan nilai dan perilaku yang berbeda.

Tabel 3 Hubungan Karakteristik Individu terhadap Penilaian Kualitas Produk Apotek Rawat Jalan RSUD Dr. Moewardi Surakarta.

\begin{tabular}{|c|c|c|c|c|c|}
\hline \multirow{3}{*}{ Karakteristik Individu } & \multicolumn{4}{|c|}{ Penilaian Kualitas Produk } & \multirow{3}{*}{$\mathbf{p}$} \\
\hline & \multicolumn{2}{|c|}{ Tinggi } & \multicolumn{2}{|c|}{ Rendah } & \\
\hline & $\mathbf{n}$ & $\%$ & $\mathbf{n}$ & $\%$ & \\
\hline \multicolumn{6}{|l|}{ Umur } \\
\hline Remaja & 10 & 58,8 & 7 & 41,2 & \multirow{3}{*}{$0,045^{\star}$} \\
\hline Dewasa & 25 & 58,1 & 18 & 41,9 & \\
\hline Lansia & 29 & 80,6 & 7 & 19,4 & \\
\hline \multicolumn{6}{|l|}{ Jenis Kelamin } \\
\hline Laki-laki & 20 & 58,8 & 14 & 41,2 & \multirow[t]{2}{*}{0,327} \\
\hline Perempuan & 44 & 71,0 & 18 & 29,0 & \\
\hline \multicolumn{6}{|l|}{ Tingkat Pendidikan } \\
\hline$\leq$ Tamat SMP & 27 & 77,1 & 8 & 22,9 & \multirow{3}{*}{0,179} \\
\hline Tamat SMA & 22 & 59,5 & 15 & 40,5 & \\
\hline Tamat PT/Akademi & 15 & 62,5 & 9 & 37,5 & \\
\hline \multicolumn{6}{|l|}{ Status Pekerjaan } \\
\hline Bekerja & 29 & 80,6 & 7 & 19,4 & \multirow[t]{2}{*}{$0,044^{*}$} \\
\hline Tidak Bekerja & 35 & 58,3 & 25 & 41,7 & \\
\hline \multicolumn{6}{|l|}{ Tingkat Pendapatan } \\
\hline$<$ UMR & 36 & 67,9 & 17 & 32,1 & \multirow[t]{2}{*}{0,179} \\
\hline$\geq$ UMR & 28 & 65,1 & 15 & 34,9 & \\
\hline
\end{tabular}


Umur dewasa memiliki cara berfikir dan mengambil keputusan yang optimal sehingga mempengaruhi bagaimana hasil penilaian terhadap kualitas produk.

Faktor usia dapat mempengaruhi pembelian suatu produk, kategori usia menyebabkan perbedaan ketertarikan dan kesukaan pada suatu produk (Sumarwan, 2004). Terdapat pula kemungkinan adanya pengaruh perbedaan usia pihak yang merencanakan marketing strategy dengan pelanggan (Kotler, dkk., 2003).

Status pekerjaan berhubungan dengan penilaian kualitas produk karena pada seseorang yang berkerja memungkinkan mendapatkan informasi mengenai suatu produk lebih banyak dibanding dengan seseorang yang tidak bekerja. Pelanggan mendapatkan motivasi dan kepercayaan diri untuk memilih dan mengambil keputusan membeli karena dorongan dari informasi yang didapat (Heitman et. al., 2007). Responden yang tidak bekerja memberikan penilaian yang lebih baik dari pada responden yang bekerja. Hal tersebut karena pekerjaan seseorang juga mempengaruhi banyak sedikitnya informasi yang didapatkan, sehingga pekerjaan seseorang mempengaruhi barang atau jasa yang dibelinya. Pasien yang berlatar belakang bekerja memungkinkan mendapatkan informasi mengenai produk yang lebih baik, sehingga memiliki tuntutan akan produk yang lebih baik dari apa yang didapatkannya. Informasi tersebut dapat membantu seseorang untuk memutuskan atau mengambil suatu keputusan untuk memanfaatkan pelayanan kesehatan untuk dirinya (Notoatmodjo, 2003 dan Heriyono, 2004). Pekerjaan merupakan salah satu faktor struktur sosial, sehingga dengan adanya pekerjaan ini akan mempengaruhi seseorang dalam memanfaatkan pelayanan kesehatan yang ada.

Berdasarkan Tabel 3 dapat diketahui bahwa terdapat beberapa karakteristik individu yang tidak berhubungan dengan penilaian dimensi kualitas produk yaitu jenis kelamin, tingkat pendidikan, dan tingkat pendapatan. Jenis kelamin tidak berhubungan dengan penilaian kualitas produk dikarenakan baik responden laki-laki dan perempuan memberikan penilaian yang tinggi terhadap penilaian kualitas produk, sehingga tidak ada perbedaan yang menonjol dari keduanya. Hal tidak sejalan dengan penelitian yang telah dilakukan oleh Zelezny dan Schultz (1999) menunjukan bahwa sebuah perilaku ditentukan oleh proses sosialisasi di mana individu dibentuk oleh norma budaya dan nilai yang diharapkan pada suatu jenis kelamin tertentu. Penilaian kualitas produk yang tinggi lebih banyak diberikan oleh perempuan. Hal tersebut dikarenakan mayoritas responden juga berasal dari jenis kelamin perempuan.

Tingkat pendidikan tidak berhubungan dengan penilaian kualitas produk. Kondisi tersebut dikarenakan kebutuhan konsumen terhadap kesehatannya dan kepercayaan kosumen terhadap produk yang disediakan di apotek instalasi rawat jalan RSUD Dr. Moewardi Surakarta. Berdasarkan Tabel 3 juga dapat diketahui pula bahwa semakin tinggi tingkat pendidikan semakin sedikit pula yang memberikan penilaian yang tinggi untuk kualitas produk. Hal tersebut dikarenakan pengetahuan seseorang berdasarkan tingkat pengetahuannya mempengaruhi tuntutan akan kualitas produk yang 
didapatkannya. Semakin tinggi tingkat pendidikan seseorang maka kemampuan seseorang dalam menerima informasi akan menjadi jauh lebih baik. Pelanggan dengan pendidian tinggi cenderung memiliki permintaan yang tinggi. Hal tersebut dikarenakan kesadaran seseorang tersebut terhadap kesehatan dan konsekuensinya dalam penggunakan layanan kesehatan lebih tinggi pula. Tingkat pendidikan mempengaruhi tingkat pengetahuan seseorang akan suatu hal dan hal tersebut mempengaruhi pula terhadap cara berperilaku seseorang (Ruditya, 2014).

Tidak terdapat hubungan antara tingkat pendapatan dengan penilaian dimensi kualitas produk. Penilaian yang tinggi diberikan mayoritas oleh pasien yang berlatar belakang memiliki pendapatan kurang dari UMR. Hal tersebut dikarenakan mayoritas responden merupakan pasien BPJS Kesehatan, sehingga pasien memberikan penilaian yang tinggi untuk kualitas produk karena produk yang didapatkan bebas biaya atau gratis. Menurut beberapa responden yang merupakan pasien BPJS, obat yang didapatkan gratis sehingga tidak perlu menuntut kualitas produk yang lebih dari apa yang telah didapatkan.

\section{SIMPULAN}

Berdasarkan hasil penelitian maka dapat ditarik beberapa kesimpulan, yaitu Pertama, penilaian kualitas produk secara keseluruhan mayoritas responden memberikan penilaian tinggi. Tujuh diantara dimensi kualitas produk yang mayoritas mendapatkan penilaian tinggi dari responden, yaitu kinerja produk, daya tahan produk, service ability, kehandalan produk, kesesuaian produk, aesthetic produk, perceived quality produk. Mayoritas responden memberikan penilaian yang rendah untuk dimensi fitur produk. Fitur produk mendapatan penilaian yang rendah karena kurangnya variasi untuk kemasan produk; Kedua, terdapat hubungan antara beberapa faktor individu dengan penilaian kualitas produk, yaitu umur responden dan status pekerjaan responden. Tidak terdapat hubungan pada faktor individu jenis kelamin, tingkat pendidikan, tingkat pendapatan pasien terhadap penilaian kualitas produk.

Saran bagi pihak Instalasi Farmasi RSUD Dr. Moewardi Surakarta adalah perlu mempertahankan kualitas produk yang sudah ada terutama pada dimensi kinerja produk, daya tahan produk, kehandalan produk, service ability, kesesuaian produk, aesthetic produk, dan perceived quality produk. Untuk fitur produk perlu adanya peningkatan dengan memberikan variasi kemasan produk agar lebih menarik. Agar kualitas produk tetap baik dimata pasien perlu adanya variasi produk berdasarkan umur pasien. Saran yang dapat diberikan untuk peneliti selanjutnya adalah penelitian yang lebih mendalam mengenai faktor lain yang berhubungan dengan penilaian kualitas produk, sehingga dapat mengatahui faktor lain yang berhubungan dengan penilaian dimensi kualitas produk selain umur dan status pekerjaan.

\section{DAFTAR PUSTAKA}

Anderson, E. W., Fomel, C., \& Lehmann, D. R. (1994). Costumer Satisfaction, Market Share, and Profitability: Findings from Sweden). Journal of Marketing, 58 (3), 53-56. 
Arifianti, R. (2013). Analisis Kualitas Produk Sepatu Tomkins pada PT. Primarindo Asia Infrastucture, Tbk Bandung. Jurnal Dinamika Manajemen, 4 (1).

Biel, A. L. (1992). How Brand Image Drives Brand Equity. Journal of Advertaising Research, 36 (6).

Brucks, M., Zeithaml, V. A., \& Naylor, G. (2000). Price and Brand Name As Indicators of Quality Dimensions for Consumer Durables. Journal of the Academy of Marketing Science, 28, 359-374. doi: 10.1177/0092070300283005.

Dobni, D., \& Zinkhan, G. M. (1990). In Search of Brand Image: A Foundation Analysis. Advances in Consumer Research, 17, 110119.

Fuchs, V. R. (1998). Who Shall Live? Health, Economics, and Social Choice. Prentice Hall.

Heitmann, M., Lehmann, D. R., \& Herrmann, A. (2007). Choice Goal Attaintment and Decision and Consumption Satisfaction. Jurnal of Marketing Research, 44, 234-250.

Heriyono. (2004). Faktor-Faktor yang Berhubungan dengan Kepatuhan Penderita Tuberkulosis Paru Melakukan Pemeriksaan Ulang Dahak pada Akhir Pengobatan Tahap Intensif di Puskesmas Wonosobo 1 Kabupaten Wonosobo. Thesis. Semarang: Universitas Diponegoro.

Hurriyati, R. (2005). Bauran Pemasaran \& Loyalitas Konsumen. Bandung: Alfabeta.

Hutapea, N. O. (2009). Buku Ajar IImu Penyakit Kulit dan Kelamin: Sifilis. Jakarta: Balai Penerbitan FKUI.

Kanuk, L. L., \& Schiffman, L. G. (2004). Perilaku Konsumen Edisi 7. Jakarta: Prentice Hall.

Koltler, P. (2004). Manajemen Pemasaran Jilid 2. Jakarta: PT. Indeks Kelompok Gramedia.

Kotler, P., \& Keller, K. L. 2009. Manajemen Pemasaran Edisi 12 Jilid 1. Jakarta.

Kotler, P. (2001). Manajemen Pemasaran: Analisis, Perencanaan, Implementasi, dan Kontrol. Jakarta: PT. Prehallindo

Kotler, P., Bowen, J., \& Makens, J. (2003). Markting for Hospitality \& Tourism 3th edition. New Jersey: Prentice Hall.

Lamb, C. W., Hair, J. F., \& Mcdaniel, C. (2001). Pemasaran Edisi Empat. Jakarta: Salemba Empat.

Menteri Kesehatan Republik Indonesia. (2004). Keputusan Menteri Kesehatan Republik Indonesia No 1197/MENKES/SK/X/2004 Tentang Standar Pelayanan Farmasi di Rumah Sakit.

Menteri Kesehatan Republik Indonesia. (2008). Keputusan Menteri Kesehatan Republik Indonesia No. 129/Menkes/SK/II/2008 Tentang Standar Minimal Pelayanan Rumah Sakit.

Mulyono, B. H., Yoestini, N. R., \& Kamal, M. (2007). Analisis Pengaruh Kualitas Produk dan Kualitas Layanan terhadap Kepuasan
Konsumen (Studi Kasus di Perumahan Puri Mediterania Semarang). Jurnal Manajemen dan Organisasi, 4 (2).

Notoatmodjo, S. (2003). Pendidikan dan Perilaku Kesehatan. Jakarta: Rineka Cipta.

Notoatmodjo, S. (2010). IImu Perilaku Kesehatan. Jakarta: Rineka Cipta.

Olson, J. C., \& Peter, J. P. (2000). Consumer Behavior: Perilaku Konsumen dan Startegi Pemasaran. Jakarta: Erlangga.

Pasuraman. (1990). SERVQUAL: Review, Critique Research Agenda. European Journal of Marketing, 1-36.

Ruditya, D. N. (2014). Faktor yang Berhubungan dengan Kepatuhan Penderita Tuberkulosis untuk Memeriksakan Dahak Selama Pengobatan (Studi di Wilayah Kerja Puskesmas Tanah Kalikedinding Kota Surabaya). Skripsi. Surabaya: Universitas Airlangga.

Ruditya, A. N. (2015). Hubungan Faktor Individu dan Faktor Sosial terhadap Penilaian Dimensi Kualitas Produk Di Apotek Rawat Jalan (Instalasi Farmasi RSUD Dr. Moewardi Surakarta). Skripsi. Surabaya: Universitas Airlangga.

Schiffman, L. G., \& Kanuk, L. L. (2000). Consumer Behavior 7th edition. New Jersey: Prentice Hall.

Sumarwan, U. (2004). Perilaku Konsumen. Bogor: Ghalia Indonesia.

Swatas, Basu, \& Handoko, T. H. (2000). Analisa dan Perilaku Konsumen. Yogyakarta: BPFE.

Tjiptono, F. (2008). Strategi Pemasaran Edisi Ketiga. Yogyakarta: Andi.

Widyaswati, R. (2010). Analisis Faktor-Faktor yang Mempengaruhi Kepuasan sehingga Tercipta Word of Mouth yang Positif pada Pelanggan Speedy di Semarang. Tesis.Semarang: Universitas Diponegoro.

Wijaksana, A. (1992). Minat Remaja dalam Pemilihan Bidang Karir pada Status Sosial Ekonomi Keluarga Tingkat Atas, Menengah, dan Bawah. Skripsi. Jakarta: Universitas Indonesia.

Yulie, A. (2008). Persepsi terhadap Kualitas Produk "Daihatsu Xenia" dengan Kepuasan Konsumen. Skripsi. Semarang: Universitas Katolik Soegijaprenata.

Zeithaml, V. A., \& Bitner, M. J. (2003). Services Marketing: Integrating Costumer Focus Across the Firm, 3rd Edition. Boston: McGraw Hill.

Zeithaml, V. A., \& Bitner, M. J. (1996). Delivering and Performing Service. Boston: McGraw Hill.

Zelezny, L., \& Schultz, P. W. (1999). Value as Predictor of Environmental Attitudes: Evidence for Consistency across 14 Countries. Journal of Environmental Psychology. 